\section{Social Construction of the of Nowadays School Success from the Perspective of the Family Involvement in Educational Act}

\section{Mihaela RUS ${ }^{1}$}

${ }^{1} \mathrm{PhD}$ student, Doctoral School of Philosophy and Socio-Political Sciences, Department of Sociology and Social Work, "Alexandru Ioan Cuza" University from Iasi,Romania;

Prof. Gr I. at Primary School "Carol I" Iasi, Romania. E-mail: mihaela30rus@yahoo.com
Abstract: The notion of "school success" is generally approached in antonymy with that of "school failure" and represents the superior performance that the student obtains in the learning activity, in correlation with the requirements of the school programs and with the aims of the national educational programs. Most of the time the student's school success is related to the activity of the school, as an institution providing education, but we must not lose sight of the fact that the factors that determine the student's education refer not only to the pedagogical influence of the school but also to the family, in the psycho-socio-physiological development of the student.

In this sense, we carried out sociological research, on a sample of 24 subjects from Iaşi County, which had as fundamental objective the social construction of the notion of school success from the perspective of parents. The questions underlying the research were established in accordance with the objectives of the research and considered, in addition to defining school success, revealing the concrete ways in which the family is involved in achieving the child's school success and the relationship they establish with the school, in order to optimize school results. The research instrument was the comprehensive interview with the 24 subjects who participated in the research. Following the processing of the data obtained from the interviews, models were developed on the basis of which the theory was progressively developed.

Keywords: school success; family involvement; instilling moral values; bachelor's degree; profession; autonomy; job satisfaction.

How to cite: Rus, M. (2021). Social Construction of the of Nowadays School Success from the Perspective of the Family Involvement in Educational Act. Logos Universality Mentality Education Novelty: Social Sciences, 10(1), 18-29. https://doi.org/10.18662/lumenss/10.1/54 


\section{Introduction}

The term "success", but also other terms in its synonymous field (yield, success, efficiency, progress, quality), is used more and more often not only in socio-human literature, but in almost all fields of activityeconomy, politics, culture. From the perspective of the field of sociology of education, "school success" or "academic success" is generally correlated with the process of summative assessments, as stated in the learning outcomes. If Kulcsár (1978) defines it from the perspective of the requirements of school norms, as a result of the concordance between them and the abilities, the interests of the student, Alexandru (1979) regards it as the activity of obtaining a superior performance in education. In analysing this concept, Stoica (1992) considers that it represents the training in students, in accordance with the requirements of school curricula, of cognitive structures (knowledge systems), operational (skills, abilities), psychometric (acquirement), affective-emotional and socio - moral (attitudes, traits of will and character)".

Cristea (2008) looks at school efficiency as a ratio between the results obtained by students in terms of using a set of resources and the pedagogical objectives expected by the education system and the educational process. York et al. (2015) believe that school success demonstrates the acquisition of skills specific to a particular educational level, which does not eliminate the prospect of the future, in which today's student must confirm school success by achieving a certain educational level or getting a job which will give to him/her an important social role.

The specialized literature in the field of sociology of education (Sadovnik, 2008) highlights a multitude of meanings that can be attributed to notions of school success - school results quantified by grades, annual average, career success represented by acquired employment status, salary obtained, job satisfaction at work, obtaining measurable skills through standardized scales, graduation rates of different levels of education or dropout rates (Popescu, 1991; Sălăvăstru, 2010).

Specialists in the field have observed that from this perspective each school trajectory has its own characteristics, which gives it uniqueness, and its analysis has a subjective character, depending on who evaluates it - the student, the teacher or the parent. The student's school results, whether quantified by grades or success in an exam, explain his/her status as a good student or poor student, but also the position he/she occupies in the family, in the social micro group. Also, the interest in a child's school results influences the status of the family in the social community, the way the family 
is perceived by society, the quality of family education (T,oc, 2016). However, the school is also perceived and evaluated according to the school results of its students. Therefore, school success becomes a benchmark of the quality of education of all those involved in the educational process - students, teachers, family, schools and local communities (Popov et al., 2015).

We can observe the tendency of the specialists to assign to one of the factors of school success -family factors, psycho-socio-physiological factors and pedagogical factors, a more important role compared to other factors. Regarding the indicators that define the impact of the family environment (Stewart, 2006) on school results, they refer to the economic situation of the family, the socio-professional status of the parents, their cultural level, the educational style they approach, family structure, intrafamilial relationships and the type of family cohesion. Steelman and Powel (1991) argue that, regardless of the scale for measuring school success, it is determined by the economic situation of the family. This explains both the length of the child's school career and school failure or dropout because a precarious economic situation underlies the family's view that investing in children's education is unprofitable and unbearable (Vlad \& Vlad, 2018).

At the same time, the financial efforts of parents for the education of children lead to the emergence of intra-family conflicts, strained relationships, and children will accumulate frustrations (Becker, 1991; Boudon, 1973). Given the above, families with poor economic status (Terrion, 2006) direct their children to short-term schooling and to occupations that allow them to enter the labour market immediately (Coleman \& Coleman, 1990; Halsey et al., 1980).

On the contrary, Bray (1995) and Stevenson \& Backer (1992) assign a more important role to cultural indicators and the level of preparation of parents in achieving school success. The authors discuss the influence of differences in the level of aspiration of parents and their attitude towards education. The cultural baggage itself, which is crystallized in the language used in the family, in its cultural practices and in the system of values that govern that family are frequently discussed by the authors mentioned. A special role is assigned by the sociologist Bernstein (1978) to the language used in the family in acquiring school-type culture, from this point of view the school success being interdependent with the linguistic performance of the student. The author assigns in particular to the mother a special role in the language acquisition by the child, this process having subsequent negative or positive consequences on the intellectual development of the child. Depending on the type of code used in intra-family communication, the form of the discourse used, the cultural content and the values that are 
transmitted through language, a causal link between social roles, communication codes and the way of expressing and transmitting verbal meanings is outlined. Maseide (1990) and Sacks (1974), delimit two categories of codes used in intra-family communication: a) restricted codes, characterized by poor vocabulary and rigid, easy, easily predictable syntax and b) elaborated codes, which differ from the first category due to the nuanced plastic vocabulary, through complex ways of organizing the sentence, so that the expression of personal ideas, thoughts and intentions is explicit. The first category of codes is accessible to all, while the second is restrictive because access to the appropriate type of social relationship is also limited. The cited authors are of the opinion that the second category of codes is closer to the one used at school, and this fact benefits children from socio-culturally advantaged families from the beginning of schooling because the language used in their families is close to the one used at school. Thus, they will be in places of continuity, strengthening previous acquisitions, while those from socio-culturally disadvantaged families will have to adapt all their values, to restructure their ability to communicate and relate.

The school performance of the students and the attitude they have towards learning are largely determined by the educational climate in the family (Pourtois \& Desmet, 1991; Stănciulescu, 1997). The parental style of the family, materialized in the nature and characteristics of the family relations in which the educational process takes place, puts its mark on the child's evolution from the point of view of the child's school situation. In recent decades we have seen a diversification of the type of family in which the child is raised and educated, from single parents, marital, reconstituted or foster families. Studies show the important role that the family type plays in achieving school success because parental divorce is a major risk factor in terms of the child's school situation (Roth et al., 2009). He/she experiences feelings of anxiety, confusion, frustration, pain, shame, guilt, and helplessness, which has serious psychological and relational problems (Behrman et al., 1995; Levy et al., 2002; Turliuc, 2004).

\section{Research development}

Given the above, we initiated the research that had as its fundamental objective the social construction of school success from the point of view of the family. In order to fulfil the fundamental object, we have established the secondary objectives that aimed at: defining the notions of school success by the parents who have children's students in different levels of education; determining the concrete way in which parents are involved in the child's education so that the children 
Social Construction of the of Nowadays School Success from the Perspective... Mihaela RUS

school results to be successful; establishing how parents interact with the school in the pursuit of school success by children.

The research questions were set according to the objectives:

1. What does school success mean for the parents of today's society?

2. What are the ways in which they understand to get involved so that their children can be successful in school?

3. What is the optimal school-family relationship, so that the collaboration between these factors leads to the achievement of school success by students?

The research took place between May 2019 and August 2020. The research instrument was the comprehensive interview, and the subjects of the research were 24 persons, parents who have children integrated in the state or private education system in Iasi County. The sampling method used to select parents was a frequently used one in sociological research - we analysed the initial interviews and identified the people who may be the initial categories that formed the grounds of the research. Following the application of the comprehensive.

\section{The research results}

Defining the notion of school success has been the concern of specialists in various fields: pedagogy and sociology of education, psychology of education, pedagogy and unanimous opinions outline it as representing the maximum performance of each school stage. However, following the research, we found that parents' opinions differ from those of specialists and evaluate school success over well-defined periods of time. The vast majority of subjects who participated in the research believe that school success can be highlighted only when the child has completed his school career and will become an active part of society, within a certain sector of activity that will ensure independence, social and financial autonomy. But there are parents who define school success from the perspective of the present, of what happens to the child at school every day, of each result obtained by the child as a result of the way in which he/she was involved for his/her own education.

Parents who define school success in terms of the present time, 25\% of those interviewed, consider that school success is represented by the grades that children get daily at school or at the end of a school, at the end of a semester or school year. From their point of view, the relationship that the child establishes with the teachers assigned to the class he/she belongs to and with his/her classmates is very important, because there are factors that can influence the achievement of the school success. From this perspective, parents 
emphasize the importance of observing the rules of moral conduct that underlie the construction of a social climate according to the instructiveeducational activities. Their opinion is that the school acts on the child with specific means and empowers him with information, knowledge, skills and abilities specific to different objects of study, and the role of the family is to educate the student according to their own culture, beliefs, traditions and conceptions about educating the child. Parents with higher education, regardless of the environment of residence, tend to be role models for their children, considering that the way they talk, behave, their concerns in their free time are reflected in the behaviour that the child adopts, not only in the family environment, but also in society, in the social micro group represented by class and school. Also, the opinion of this category of parents is that certain skills of study, continuous improvement, leisure are formed within the family. Also in this environment, certain socio-cultural habits are formed that positively or, on the contrary, negatively influence the child's school trajectory.

Parents with higher education with an urban background define school success as the product of a number of factors, including the school in which the child is enrolled. Thus, they consider it crucial to choose a prestigious school, which provides a higher education and which has demonstrated this over time, through the results obtained by students who graduated from that school in school competitions or exams for access to a higher level of education. From this perspective, it is important to involve them in choosing a school that meets the goals they have set for the child's school life because the teaching staff can facilitate the success of the school. Closely related to choosing the right school for their child is the choice of the teacher (s) with whom the child will come into contact. Especially when the child starts his/her school life, the parents allocate time and energy to enrol the child in a well-rated teacher, who has shown through results, over time, that he/she (the teacher) is very well prepared. The teacher is the one who has the mission to integrate the child in the school environment, different from the preschool one, both by the nature and structure of the learning organization, and by objective requirements stipulated by clear learning objectives. In primary school, the foundations are laid for knowledge and skills that the child will use throughout his/her life: reading, writing, counting, problem solving, oral and written expression.

Defining school success from the perspective of the present time, the family refers to the importance of individual study, to the systematic thorough preparation of the child. Parents are involved in the rational organization of the child's extracurricular time, so that he enjoys mental comfort and relaxation, given that the learning activity is a long-term one. Where possible, they acknowledge that they are involved in homework and 
support in doing so, and if they feel overwhelmed by the content of the curriculum for certain subjects, they turn to specialists with whom the children work in private. One of the subjects even states that he is studying with the children, that he resumed the whole subject with them in order to be able to support them in the thorough preparation. From this point of view, we observed a general feature of the subjects participating in the comprehensive interview, regardless of the environment of residence or level of education, namely the active involvement of the mother in the daily preparation of the child, but also the role it assumes in creating a family environment conducive to the child's learning and education. Male subjects acknowledge that they are not involved in supporting children in their learning activity and believe that their role is to provide them with optimal material conditions and to spend constructive free time with children.

Also, from the perspective of defining school success, we now observe in subjects with higher education the concern to include the child in extracurricular activities because they have the role of identifying and perfecting skills or talents with which children are endowed, in stimulating creative behaviour in certain fields. At the same time, from their point of view, this type of activity is a form of education that has the role of facilitating the positive transfer of knowledge, skills and abilities formed in school from theory to practice. Therefore, through this type of activity, learning will be thorough, long-lasting and will contribute to school success. The parents bring into discussion another aspect, not to be neglected, and certain that involving the child in different activities, he/ she will become familiar with different fields of activity-sports, artistic, cultural, so that in the future, when be/ she will be put in the position of to choose a profession, to select it knowingly. Parents complain that modern technology is being used excessively, and through extracurricular activities children have the opportunity to spend their free time actively and pleasantly, to socialize with their peers. These activities become all the more effective when they start at an early age and take place in a parent-child tandem, giving them the chance to communicate more with their children and thus get to know them better. In conclusion, the extracurricular activities in which children are currently involved help him/ her to become autonomous in the future, with solid moral principles and optimally integrated in society. So, the extracurricular activities add value to the educational process exercised by the school on the child.

At the current time, parents in urban areas with higher education also define their school success from the perspective of their children's motivation for learning (Schunk et al., 2008). This is all the more effective as their intrinsic motivation becomes rooted in the child's aspirations. Parents believe that the motivation for learning is formed from 
early childhood, when the child's education is mainly in the family and is a prerequisite for school success (Brunel, 1999; Cretu, 1997). The happiest situation is when the child's aspirations are in line with those of the parents. Parents in rural areas with secondary education believe that the formation of motivation (Sadovnik, 2008) to achieve school success may be based on their own failures, failures that have marked their school career. From their point of view, school success represents overcoming the social and professional condition of parents.

Female subjects, both urban and rural, are concerned with ensuring the emotional balance of the child. In this sense, communication with the child is essential because depending on the positive or negative emotions that he experiences at a given time, the family can act accordingly. At the same time, the involvement of the family in the emotional life of the child, according to the subjects, proves to him/her the care that the family has for him/her, a fact that will give him/her confidence in himself, in his own strength and in those around him. Parent-child communication must not be one-sided, effective communication, say the researchers, involves an exchange of ideas, beliefs, drawing conclusions.

Unlike subjects with urban residency, all 12 subjects in rural areas focus, when talking about the child's education and school success, the child's behaviour in society, in the social environment in which he/she is integrated at a given time. In their view, the current role of the family is to form habits of civilized behaviour, in accordance with local traditions and culture. The "seven years at home" are the responsibility of the family, while the role of the school is to equip all children with information, skills, attitudes and behaviour specific to the topics of learning activities. The education that the child receives in the family is important, in their view, not only for achieving current school success, but also for the future integration of the adult in society as an active member of it, as a professional. Thus, the future adult will not only be able to ensure his/her autonomy, that he/she will be successful from a professional point of view, but he/she will also be useful to society and will contribute to the development of society. Especially secondary education subjects from rural areas are morally concerned with educating children. This is explained by the fact that those rural communities are small, and each member of the community knows everyone else, and inappropriate behaviour of the child would be immediately observed, judged and subjected to the disgrace of the community.

It is also well known that in rural communities, conservatism and traditionalism are still predominant, in terms of outfit people wear, communication manner. Another explanation for the concern of the rural family to transfer moral values to their children is that, in general, the 
education of their parents does not allow them to help their children in various fields, so their involvement in children's education is limited to training children from a moral point of view, the rest will be taken care of by the school, through specialized teachers. The importance that rural subjects assign to the "seven years at home" also consists in the fact that this is the basis on which the school will build the future specialist, in the field that the child will choose. Whatever that field will be, the future adult will have to be primarily a good human, a responsible adult and involved person in the social life of the society and the social micro group of which he/she will be part of. The subjects consider that the lack of concern of the family for the moral-civic education of the little ones can be the basis of the school failure and the appearance of even worse situations than this: school dropout and juvenile delinquency.

Offering the definition of school success from the perspective of the present time, a number of interviewees believe that this is the individual effort that each child makes for their own education. Especially male subjects encourage children to achieve school success through their own efforts, from the perspective of the fact that each moment must be used judiciously for their own training. This gives children a work style that will become a characteristic feature over time, a way of being and behaving when they become adults. If, as mentioned above, female subjects are involved in the effort of children to prepare for school in order to achieve school success, male parents are at the opposite pole. In particular, rural subjects do not pay much attention to school results, it is important for children to promote the class and avoid of being in the need of corrigent situation on particular learning disciplines. They focus on the child's psychological comfort and the way he/she establishes the relationship with the members of the social micro group in which he/she is integrated - teachers and classmates, but also on the development of activities specific to the child's age.

\section{Conclusions}

In conclusion, the definition of school success from the perspective of the present time, it represents its immediate results which are reflected in grades, semester and annual tests results. Parents who define school success from this perspective are involved in the daily preparation of children for school: homework, creating an appropriate environment to support to the child's intellectual activities, inclusion in extracurricular activities that take place systematically and organized in children's clubs, offering support through specialized teachers with whom the child works in private. Mainly the subjects with higher education who participated in the research currently 
define the school success through results in high scores at the end of the schooling year, while those with secondary education are focusing on the formation of moral skills.

\section{References}

Alexandru, J. (1979). Dicţionar de pedagogie [Dictionary of pedagogy]. Didactică şi Pedagogică.

Becker, G. (1991). A Treatise on the Family. Harvard University Press.

Behrman, J., Pollak, R., \& Taubman, P. (1995). From parents to child: Intrabousehold allocations and intergenerational relations in the United States. Chicago University Press.

Bernstein, B. (1978). Studii de sociologie a educatiei [Studies in the sociology of education]. Didactică şi Pedagogică.

Boudon, R. (1973). Linegalité des chances [Inequality of opportunity]. Armand Colin.

Bray, J. (1995). Family assessment: current issues in evaluating families. Family Relations, 44(4), 469-477. https://doi.org/10.2307/585001

Brunel, P. C. (1999). Relationship between achievement goal orientations and perceived motivational climate on intrinsic motivation. Scandinavian Journal of Medicine \& Science in Sports, 9(6), 365-374. https://doi.org/10.1111/i.1600-0838.1999.tb00258.x

Coleman, J. S., \& Coleman, Z. W. (1990). Equality and Achievement in Education. Westview Press.

Crețu, C. (1997). Psibopedagogia succesului [Psychopedagogy of success]. Polirom.

Cristea, G. C. (2008). Pedagogie generală [General pedagogy]. Didactică şi Pedagogică.

Halsey, A. H., Heath, A. F., \& Ridge, J. M. (1980). Origins and Destinations. Family, Class and 14 Education in Modern Britain. Clarendon Press.

Kulcsár, T. (1978). Factorii psihologici ai reusitei scolare [Psychological factors of school success]. Didactică şi Pedagogică.

Levy, R., Widmer, E., \& Kellerhals, J. (2002). Modern family or modernized family traditionalism?: Master status and the gender order in Switzerland. Electronic Journal of Sociology, 6(4). https://serval.unil.ch/resource/serval:BIB 24302.P001/REF

Maseide, P. (1990). The social construction of research information. Acta Sociologica, 33(1), 3-13. https://doi.org/10.1177/000169939003300101

Popescu, V. V. (1991). Succesul şi insuccesul şcolar-precizări terminologice, forme de manifestare, cauze [School success and failure - terminological clarifications, forms of manifestation, causes]. Revista de pedagogie, 12. 
Social Construction of the of Nowadays School Success from the Perspective... Mihaela RUS

Popov, N., Wolhuter, C., Ermenc, K. S., Hilton, G., Ogunleye, J., \& Niemczyk, E. (Eds.). (2015). Quality, social justice and accountability in education worldwide. Bulgarian Comparative Education Society. https://files.eric.ed.gov/fulltext/ED568595.pdf

Pourtois, J. P., \& Desmet, H. (1991). Quelques déterminants familiaux de la trajectoire scolaire et sociale [Some family determinants of school and social trajectory]. Revue Française de Pedagogie, 96, 5-15. https://www.persee.fr/doc/rfp 0556-7807 1991 num 9611343

Roth, M., Hărăguş, P.T., Dămean, D., Mezei, E. (2009). Dimensiunile sociale ale succesului şcolar. In M. Roth, D. Dămean, D. \& M. Iovu (Eds.), Succesul scolar la intersectia factorilor sociali [School success at the intersection of social factors]. Presa Universitară Clujeană.

Sacks, H. (1974). On analysabily of stories by children. In R. Turner (Ed.), Ethnomethodology. (pp. 216-236). Penguin.

Sadovnik, A. R. (2008). Contemporary Perspectives in the Sociology of Education. In J. H. Ballantine \& J. Z. Spade (Eds.), Schools and Society. Pine Forge Press.

Sălăvăstru, D. (2004). Psihologia educației [The psychology of education]. Polirom.

Schunk, D. H., Pintrich, P. R., \& Meece, J. L. (2008). Motivation in education. (3rd ed.). Pearson.

Stănciulescu, E. (1997). Sociologia educației familiale [Sociology of family education]. Polirom.

Steelman, L. C., \& Powell, B. (1991). Sponsoring the next generation: Parental willingness to pay for higher education. American Journal of Sociology, 96(6), 1505-1529. https://doi.org/10.1086/229695

Stevenson, D. L., \& Backer, D. (1992). Shadow Education and Allocation in Formal Schooling: Transition to University in Japan. American Journal of Sociology, 97(6), 1639-1657. http://doi.org/10.1086/229942

Stewart, E. B. (2006). Family and Individual-Level Predictors of Academic Success for African American Students: A Longitudinal Path Analysis Utilizing National Data. Journal of Black Studies, 36(4), 597. https://doi.org/10.1177/0021934705276798

Stoica, M. (1992). Sinteze de pedagogie sii psibologie [Synthesis of pedagogy and psychology]. Universitară Craiova.

Terrion, J. L. (2006). Building Social Capital in Vulnerable Families: Success Markers of a School-Based Intervention Program. Youth and Society, 38(2), 155-176. http://dx.doi.org/10.1177/0044118X05282765

Țoc, S. (2016). Familie, şcoală şi succes şcolar în învăţământul liceal românesc [Family, school and school success in Romanian high school education]. Revista "Calitatea vieții", 27(3), 189-215. https://revistacalitateavietii.ro/2016/CV-3-2016/01.pdf 
Turliuc, M. N. (2004). Psibologia copilului si a familiei [Child and family psychology]. Performantica.

Vlad, R., \& Vlad, M. (2018). School Success and Failure-determinants factors and ways top recent school failure. Journal of Romanian Literary Studies, 14, 340343. https://old.upm.ro/jrls/JRLS-14/Rls\%2014\%2047.pdf

York, T., Gibson, C., \& Rankin, S. (2015). Defining and Measuring Academic Success, Practical Assessment, Research \& Evaluation, 20, 5.

https://doi.org/10.7275/hz5x-tx03 